\title{
HUBUNGAN ANTARA PENANGANAN DIABETES MELITUS: EDUKASI DAN DIET TERHADAP KOMPLIKASI PADA PASIEN DM TIPE 2 DI POLIKLINIK RSUP DR. HASAN SADIKIN BANDUNG
}

\author{
Hilda Novyanda ${ }^{1}$, Wini Hadiyani ${ }^{2}$ \\ ${ }^{1,2}$ Sekolah Tinggi Ilmu Keperawatan PPNI Jawa Barat \\ Jl. Muhammad No. 34A Bandung 40173 \\ Telp. 022-6004498, 022-6121914, Fax.022-6121914 \\ Email: novyanda_hilda@ymail.com
}

\begin{abstract}
Abstrak
Diabetes Melitus (DM) adalah penyakit seumur hidup dimana badan seseorang tidak memproduksi cukup insulin atau tidak dapat menggunakan insulin yang diproduksi dengan baik (Johnson, Marilyn 2005). Peningkatan komplikasi DM meningkat setiap bulannya di Poliklinik Endokrin RSHS Bandung. Tujuan penelitian ini adalah untuk mengetahui hubungan antara penanganan DM: Edukasi dan Diet terhadap komplikasi pada pasien DM Tipe 2 di Poliklinik RSUP Dr. Hasan Sadikin Bandung. Penelitian ini merupakan penelitian deskriptif korelasi dengan desain retrospektif dengan populasi sebanyak 95 orang dengan teknik pengambilan sampel purposif sampling dan didapatkan sampel sebanyak 50. Analisa data diolah menggunakan uji Chi-Square Test. Hasil penelitian ini mendapatkan hubungan yang signifikan antara edukasi mengenai DM dengan komplikasi didapatkan nilai $p$ value $(0,041)$ dengan $\alpha(5 \%)$ dan untuk hubungan antara kepatuhan diet DM dengan kejadian komplikasi mendapatkan hubungan yang signifikan dengan didapatkan nilai $p$ value $(0,020)$ dengan $\alpha(5 \%)$. Untuk itu disarankan khususnya kepada responden agar ikut serta jika ada penyuluhan yang diberikan oleh tenaga kesehatan serta patuh terhadap pilar penanganan DM khususnya Diet DM yang dianjurkan oleh tenaga kesehatan.
\end{abstract}

Kata kunci : Edukasi, Diet, Diabetes-Mellitus

\begin{abstract}
Diabetes mellitus is a life long disease in which a person's body does not produce enough insulin or can not use insulin produced properly (Johnson \& Marilyn 2005). Endocrine Polyclinic Hospital Dr. Hasan Sadikin Bandung in February 2014 showed that many cases of diabetes complications that occur and increasing every month. The aim of this study was to determine the relationship of Education regarding the incidence of diabetes complications and determine the relationship between dietary DM with the incidence of complications. The study design used retrospective descriptive correlation. The study population was people with DM with a sample of 50, the sampling used purposive sampling 50. The results showed a significant relationship between education about diabetes complications $p$ value (0.041) and the relationship between compliance diet with the incidence of diabetes complications getting significant association with $p$ value (0.020). It recommended especially to the respondents in order to take part if there was counselinggivenby health workers as well as adherence to the pillars of diet DM in particular diabetes treatment that recommended by health professionals.
\end{abstract}

Keywords: Education, Diabetes-Mellitus, Diet-DM 


\section{PENDAHULUAN}

Diabetes Melitus merupakan penyakit seumur hidup, dimana tubuh tidak memproduksi cukup insulin atau tidak mampu menggunakan insulin yang diproduksi dengan baik (Johnson, Marilyn 2005). Diabetes Melitus (DM) merupakan masalah kesehatan terbesar didunia. Menurut World Health Organization (WHO, 2006), DM penyebab ke-20 atau 1,4\% dari penyebab disabilitas di dunia. Prevalensi DM diseluruh dunia diperkirakan meningkat 4,45\% di tahun 2030. Di Indonesia, penderita penyakit ini meningkat dari 8,4 juta menjadi 21,3 juta dari total penduduk dalam kurun waktu 30 tahun (Rubiatun, 2010).

Menurut Holt et. al. (2010), penyebab penyakit DM beragam sesuai dengan karakteristik adanya hiperglikemia kronis yang disertai dengan gangguan metabolisme karbohidrat, protein dan lemak sebagai akibat dari gangguan sekresi insulin dan penurunan aktivitas insulin. Penyakit DM terdiri dari dua tipe yaitu: (1) penderita DM baik itu Tipe I (Insulin Dependent Diabetes Mellitus) biasanya diakibatkan oleh keturunan dan (2) DM tipe kedua yang disebabkan oleh life style atau gaya hidup atau biasa disebut Tipe II (Non Insulin Dependent Diabetes Mellitus) (Norris, et al., 2002). DM Tipe II lebih sering terjadi yaitu sekitar 90\% - 95\% dari semua yang menderita Diabetes (ADA, 2010). Penderita DM Tipe II pemiliki peningkatan resiko terjadinya komplikasi yang mengancam jiwa. Dua jenis komplikasi vaskuler yang mungkin timbul pada DM tipe II, yaitu komplikasi makrovaskuler (jantung koroner, penyakit serebrovaskuler, stroke dan penyakit vaskuler perifer) dan komplikasi mikrovaskuler (retinopati, nefropati dan neuropati diabetikum (Smeltzer dan Bare, 2002).
Salah satu tingginya prevalensi DM, terutama yang tergolong DM tipe-2 disebabkan oleh interaksi antara faktor-faktor kerentanan genetis dan paparan terhadap lingkungan. Faktor lingkungan yang menjadi faktor risiko DM tipe-2 yaitu perubahan gaya hidup dan aktifitas fisik. Kebiasaan makan yang tidak baik menyebabkan obesitas dan aktifitas fisik yang kurang menjadi faktor risiko dalam memicu terjadinya DM.

Berdasarkan informasi American Diabetes Association (ADA) 2005, ada peningkatan drastis komplikasi penyakit diabetes sejak 2001 hingga 2004. Pada 2001, penderita DM beresiko mengalami penyakit kardiovaskuler hingga 32\%. Sedangkan pada tahun 2004 angkanya meningkat $11 \%$, yaitu mencapai 43\%. Tahun 2001, 38\% penderita DM mengalami hipertensi. Tahun 2004 angkanya mencapai $69 \%$ atau meningkat $31 \%$ (Wulandari, 2009). Apabila dibandingkan dengan orang normal, maka penderita DM $5 \mathrm{x}$ lebih besar untuk timbul gangren, $17 \mathrm{x}$ Iebih besar untuk menderita kelainan ginjal dan 25 $\mathrm{x}$ lebih besar untuk terjadinya kebutaan (Permana, 2009 dikutip Meydani 2011). Komplikasi pada DM lebih sering mengakibatkan kematian dibandingkan dengan hiperglikemia yang diderita penyakit DM.

Penyakit DM memiliki risiko terjadinya komplikasi dan dapat mengancam jiwa apabila tidak segera ditangani dan tidak dilakukan pengontrolan yang tepat. Ada 4 pilar yang perlu dijalankan agar penyakit DM dapat dikontrol sehingga tidak berdampak pada komplikasi yang lebih berat, yaitu: Edukasi, Pengaturan Makan, Olahraga/ gerak badan, Obat: tablet atau insulin (Kariadi, 2009).

Pengaturan makan atau kepatuhan diet merupakan salah satu faktor untuk menstabilkan kadar gula dalam darah menjadi 
normal dan mencegah komplikasi. Adapun faktor yang mempengaruhi seseorang tidak patuh terhadap diet DM adalah kurangnya pengetahuan terhadap penyakit DM, sikap, keyakinan, dan kepercayaan yang dimiliki klien. Ketidakpatuhan terhadap diet DM akan menyebabkan terjadinya komplikasi akut dan kronik pada akhirnya memperparah penyakit bahkan bisa menimbulkan kematian (Lanywati, 2001).

Pengetahuan pasien tentang DM yang rendah dapat mempengaruhi persepsi pasien tentang penyakitnya, motivasi, manajemen koping dan perubahan perilaku (Sousa \& Zauseniewski, 2005). Hasil penelitian oleh Ariani dan Misdarini (2012) didapatkan bahwa mayoritas pasien memiliki tingkat pengetahuan yang kurang sebanyak 54,9\% dan kadar gula darah pasien rata-rata 246,9 $\mathrm{mg} / \mathrm{dl}$. Rendahnya pengetahuan yang dimiliki responden mengenai penyakit DM berdampak pada ketidakmampuan responden dalam mengontrol kadar gula darah sehingga kadar gula darah menjadi tinggi. Penelitian lainnya yang berkaitan dengan pengetahuan terhadap penyakit DM dilakukan Lestari, dkk (2013) terhadap 29 responden diperoleh sebagian besar responden $(65,5 \%)$ memiliki pengetahuan kurang, dan 58,6\% sikap negatif, $89,7 \%$ tidak patuh mengkonsumsi jumlah kalori, $100 \%$ tidak patuh jadwal makan, dan $65,5 \%$ tidak patuh mengkonsumsi jenis makanan, kadar GDS (Gula Darah Sewaktu) responden sebesar $65,5 \%$ tidak terkontrol. Kedua penelitian ini menyatakan pengetahuan tentang DM berdampak pada kepatuhan terhadap diet DM dan kadar gula darah. Pengetahuan penderita tentang DM merupakan sarana yang dapat membantu penderita menjalankan penanganan diabetes selama hidupnya sehingga semakin banyak dan semakin baik penderita mengerti tentang penyakitnya semakin mengerti bagaimana harus mengubah perilakunya dan mengapa hal itu diperlukan (Waspadji, 2007).

Dalam profil kesehatan Kota Bandung tahun 2011 didapatkan data kasus DM rawat jalan di PUSKESMAS umur 48-59 tahun sebanyak 6.388 dan umur $>70$ tahun sebanyak 1.266 kasus baru. Kasus DM rawat jalan di Rumah Sakit umur 45-64 tahun sebanyak 5.418 kasus dan umur $>65$ tahun sebanyak 2.171 kasus dan kasus DM rawat inap di Rumah Sakit umur 45-64 tahun sebanyak 895 dan umur $>65$ tahun sebanyak 459 kasus. (DinKes Kota Bandung, 2011).

Hasil rekam medis di poliklinik endokrin RSUP Dr. Hasan Sadikin Bandung (2013) angka kejadian penderita diabetes dengan komplikasi perbulan dari bulan Juli hingga bulan September 2013 didapatkan hasil : bulan Juli jumlah kunjungan pasien DM sebanyak 388 orang, dan 55 pasien (14\%) mengalami komplikasi. Bulan Agustus jumlah kunjungan pasien DM sebanyak 355 orang, dan 101 pasien (29\%) mengalami komplikasi. Bulan September dengan kunjungan pasien DM 309 orang, dan 131 orang (42\%) mengalami komplikasi. Dari beberapa kasus komplikasi yang terjadi di Poliklinik Endokrin RSUP Dr. Hasan Sadikin Bandung adalah komplikasi terbanyak yaitu: Renal, Neorologi, Perifer Sirkulasi dan Optalmic (Rekam Medis Poli Endokrin, 2013).

Hasil wawancara yang dilakukan pada bulan Februari 2014 terhadap 6 pasien bahwa seluruh pasien teratur mengkonsumsi obat, 3 dari 6 pasien tahu mengenai DM tetapi 5 dari 6 klien yang di wawancara tidak patuh terhadap diet yang diberikan oleh petugas kesehatan dan bahkan seluruh pasien tidak melakukan aktivitas fisik/ olah raga serta seluruh pasien yang diwawancara mengalami komplikasi diantaranya: Penurunan Visus, 
Hubungan Antara Penanganan Diabetes Melitus : Edukasi dan Diet terhadap Komplikasi Pasien DM Tipe II (Hilda Novyanda)

Gangren Diabetik, Hipertensi, Stroke, Gagal ginjal dan Hipoglikemi.

Dari hasil studi pendahuluan yang diadakan di Poliklinik Endokrin RSUP Dr. Hasan Sadikin Bandung pada bulan Februari 2014 menunjukkan bahwa banyak kasus komplikasi diabetes yang terjadi dan meningkat setiap bulannya. Seluruh pasien yang diwawancara mengalami komplikasi mengatakan tidak patuh diet dan tidak melakukan aktivitas fisik/ olahraga karena kepatuhan diet serta aktivitas fisik juga tidak hanya edukasi dan kepatuhan obat saja yang dapat menurunkan glukosa, tetapi faktor kepatuhan diet serta melakukan aktivitas olahraga juga berpengaruh untuk menurunkan glukosa darah dan untuk pencegahan komplikasi.

\section{METODE PENELITIAN}

Desain penelitian cross sectional. Responden yang digunakan 50 orang yang memiliki komplikasi yang berobat di Poliklinik RSUP Dr. Hasan Sadikin Bandung. Pengambilan sampel menggunakan non-probability sampling. Teknik pengumpulan data menggunakan kuesioner dan lembar observasi. Analisis Univariat menggunakan distibusi frekuensi, sedangkan bivariat menggunakan chi square. Analisis bivariat bertujuan untuk melihat hubungan antara variabel independen (Edukasi dan Diet) dan variabel dependen (kejadian komplikasi). Pelaksanaan penelitian dilaksanakan di Poli klinik Endokrin RSUP Dr. Hasan Sadikin Bandung.

\section{HASIL PENELITIAN}

Tabel 1.

Distribusi Frekuensi Karakteristik Responden di Poliklinik Endokrin RSUP Dr. Hasan Sadikin Bandung

\begin{tabular}{llcc}
\hline Karakteristik & & & \\
\hline 1. Identitas Pasien & & $\mathbf{N}$ & $\mathbf{\%}$ \\
a. Jenis Kelamin & Perempuan & $\mathbf{2 9}$ & $\mathbf{5 8}$ \\
& Laki-laki & 21 & 42 \\
\hline & Total & $\mathbf{5 0}$ & $\mathbf{1 0 0}$ \\
\hline b. Usia & $30-40$ & 5 & 10 \\
& $40-60$ & $\mathbf{2 7}$ & $\mathbf{5 4}$ \\
& $60-80$ & 18 & 36 \\
\hline & Total & $\mathbf{5 0}$ & $\mathbf{1 0 0}$ \\
\hline c. Pendidikan & SD & 10 & 20 \\
& SMP & 13 & 26 \\
& SMA & 13 & 26 \\
& Perguruan Tinggi & $\mathbf{1 4}$ & $\mathbf{2 8}$ \\
\hline & Total & $\mathbf{5 0}$ & $\mathbf{1 0 0}$ \\
\hline d. Lama Menderita & $<1$ tahun & 11 & 22 \\
& $1-2$ tahun & 8 & 16 \\
& $>$ 2tahun & $\mathbf{3 1}$ & $\mathbf{6 2}$ \\
\hline & Total & $\mathbf{5 0}$ & $\mathbf{1 0 0}$ \\
\hline
\end{tabular}

Berdasarkan tabel diatas lebih dari setengahnya (58\%) berjenis kelamin laki-laki, 54\% usia 60-70 tahun, sebagian kecil $28 \%$ pendidikan perguruan tinggi dan lebih dari setengahnya $62 \%$ telah $>2$ tahun mengidap penyakit DM. 
Tabel 2.

Distribusi Frekuensi Karakteristik Responden

Berdasarkan Edukasi mengenai Diabetes

Mellitus di Poliklinik Endokrin RSUP

Dr. Hasan Sadikin Bandung

\begin{tabular}{lcc}
\hline Edukasi & $\mathbf{N}$ & $\mathbf{\%}$ \\
\hline Baik & $\mathbf{3 9}$ & $\mathbf{7 8}$ \\
Buruk & 11 & 22 \\
\hline Total & $\mathbf{5 0}$ & $\mathbf{1 0 0}$ \\
\hline
\end{tabular}

Analisis tabel diatas menunjukkan bahwa sebagian besar (78\%) mempunyai edukasi yang baik mengenai Diabetes Mellitus.
Tabel 3.

Distribusi Frekuensi Karakteristik Responden Berdasarkan Diet Diabetes Mellitus di Poliklinik Endokrin RSUP Dr. Hasan Sadikin Bandung

\begin{tabular}{lcc}
\hline Diet & $\mathbf{N}$ & $\mathbf{\%}$ \\
\hline Baik & $\mathbf{3 8}$ & $\mathbf{7 6}$ \\
Buruk & 12 & 24 \\
\hline Total & $\mathbf{5 0}$ & $\mathbf{1 0 0}$ \\
\hline
\end{tabular}

Analisis tabel diatas menunjukkan sebagian besar (76\%) melakukan diet DM dengan baik

Tabel 4.

Hubungan Edukasi mengenai Diabetes Mellitus dengan Kejadian Komplikasi di Poliklinik Endokrin RSUP Dr. Hasan Sadikin Bandung

\begin{tabular}{|c|c|c|c|c|c|c|c|c|c|}
\hline \multirow{3}{*}{ Edukasi } & \multicolumn{4}{|c|}{ Komplikasi } & \multirow{2}{*}{\multicolumn{2}{|c|}{ Total }} & \multirow{3}{*}{$X^{2}$} & \multirow{3}{*}{$\begin{array}{c}p- \\
\text { value }\end{array}$} & \multirow{3}{*}{ OR 95\% CI } \\
\hline & \multicolumn{2}{|c|}{ Ya } & \multicolumn{2}{|c|}{ Tidak } & & & & & \\
\hline & $\mathbf{N}$ & $\%$ & $\mathbf{N}$ & $\%$ & $\mathbf{N}$ & $\%$ & & & \\
\hline Baik & 16 & 41 & 23 & 59 & 39 & 78 & 4,19 & 0,04 & $6,46(1,230-34,012)$ \\
\hline Buruk & 9 & 82 & 2 & 18 & 11 & 12 & & & \\
\hline Total & 25 & 50 & 25 & 50 & 50 & 100 & & & \\
\hline
\end{tabular}

Hasil analisis hubungan antara edukasi dengan kejadian komplikasi pada hasil analisis didapatkan adanya dengan nilai $(\mathrm{p}=0,041)$. Nilai $\mathrm{OR}=6,469(1,230-34,012)$.

Tabel 5.

Hubungan Diet Diabetes Mellitus dengan Kejadian Komplikasi di Poliklinik Endokrin RSUP Dr. Hasan Sadikin Bandung

\begin{tabular}{|c|c|c|c|c|c|c|c|c|c|}
\hline \multirow{3}{*}{ Diet } & \multicolumn{4}{|c|}{ Komplikasi } & \multirow{2}{*}{\multicolumn{2}{|c|}{ Total }} & \multirow{3}{*}{$\mathbf{X}^{2}$} & \multirow{3}{*}{$\begin{array}{c}\mathbf{P} \\
\text { Value }\end{array}$} & \multirow{3}{*}{ OR $95 \%$ CI } \\
\hline & \multicolumn{2}{|c|}{ Ya } & \multicolumn{2}{|c|}{ Tidak } & & & & & \\
\hline & $\mathbf{N}$ & $\%$ & $\mathbf{N}$ & $\%$ & $\mathbf{N}$ & $\%$ & & & \\
\hline Baik & 15 & 39,5 & 23 & 60,5 & 38 & 76 & 5,373 & 0,020 & $7,667(1,470-39,987)$ \\
\hline Buruk & 10 & 83,3 & 2 & 16,7 & 12 & 24 & & & \\
\hline Total & 25 & 50 & 25 & 50 & 50 & 100 & & & \\
\hline
\end{tabular}

Hasil analisis didapatkan adanya Hubungan yang signifikan antara Diet DM pasien dengan kejadian komplikasi $(\mathrm{p}=0,020)$. Nilai OR = 7,667 $(1,470-39,987)$.

\section{PEMBAHASAN}

\section{Analisis Univariat}

Temuan penelitian mengenai edukasi yang dimiliki responden menggambarkan hampir seluruhnya yaitu $78 \%$ memiliki edukasi yang baik. Hal ini akan berdampak pada kondisi pengetahuan responden mengenai DM. Pada karakteristik responden didapatkan bahwa pendidikan responden paling banyak berpendidikan formal perguruan tinggi, hal ini juga dapat mempengaruhi persepsi dan 
motivasi responden terhadap edukasi DM. Edukasi merupakan dasar utama untuk pengobatan dan pencegahan DM yang sempurna. Pengetahuan yang minim tentang DM akan lebih cepat menjurus ke arah timbulnya komplikasi dan hal ini merupakan beban bagi keluarga dan masyarakat (Agustina, 2009). Tingkat pengetahuan yang rendah akan dapat mempengaruhi pola makan yang salah sehingga menyebabkan kegemukan, yang akhirnya mengakibatkan kenaikan kadar glukosa darah (Witasari, 2009).

Temuan mengenai diet DM pada hasil penelitian ini menyatakan responden memiliki diet DM yang baik yaitu hampir seluruhnya yaitu $76 \%$. Kepatuhan terhadap diet DM berkaitan dengan edukasi yang baik. Hasil penelitian yang dilakukan oleh Yoga (2011) didapatkan odds ratio (OR) sebesar 4,297 dan nilai $p=0,008 \quad(<0,05)$ hal ini menunjukkan bahwa orang yang mempunyai pola makan baik berisiko 4 kali untuk berhasil dalam pengelolaan DM tipe 2 dibandingkan dengan yang tidak baik dan secara statistik bermakna dalam mengkonsumsi jumlah kalori seperti kurang atau berlebih akan memberikan dampak pada penderita DM. Apabila konsumsi kalori kurang, maka penderita DM akan mudah mengalami penurunan berat badan karena tidak terpenuhinya kebutuhan energi. Sebaliknya, konsumsi kalori yang tinggi akan meningkatkan kadar glukosa dalam darah sehingga akan menambah beban glukosa darah penderita DM (Abduracchin, dkk, 2008).

\section{Analisis Bivariat}

\section{Hubungan antara Edukasi dan Kejadian Komplikasi}

Temuan penelitian mengenai hubungan antara edukasi dan kejadian komplikasi berdasarkan tabel diatas didapatkan nilai $p$-value $=0$, disimpulkan bahwa ada hubungan yang signifikan antara edukasi mengenai DM dengan kejadian komplikasi pada pasien DM tipe 2 . Rendahnya pengetahuan yang dimiliki responden akan mengakibatkan kadar gula darah menjadi tinggi (Misdarini \& Ariani, 2012). Tingkat pengetahuan yang rendah akan dapat mempengaruhi perilaku kesehatan termasuk pola makan yang salah yang akhirnya akan mengakibatkan kenaikan kadar glukosa darah. Hal ini terjadi karena tingginya asupan karbohidrat dan rendahnya asupan serat. Semakin rendah asupan karbohidrat, semakin rendah kadar glukosa darah. Kandungan serat yang tinggi dalam makanan akan mempunyai indeks yang rendah sehingga dapat memperpanjang pengosongan lambung yang dapat menurunkan sekresi insulin dan kolesterol total dalam tubuh (Pratiwi, 2007). Gula darah yang tinggi akan menimbulkan komplikasi seperti hasil dari The United Kingdom Prospective Diabetes Study (UKPDS) yang membuktikan bahwa kontrol glikemik dengan intensif sangat berhubungan erat dengan keuntungan klinis pada DM tipe 2. Setiap penurunan HbA1c $1 \%$ akan menurunkan insiden kematian yang berhubungan dengan DM sebesar 21\%, infark miokard $14 \%$, komplikasi mikrovaskular $37 \%$ dan penyakit pembuluh darah perifer $43 \%$. Diabetes Study (UKPDS) menunjukkan setiap penurunan $1 \%$ dari HbAlc akan menurunkan risiko komplikasi sebesar $35 \%$.

Hasil penelitian ini sejalan dengan Fred dalam penelitiannya menyimpulkan bahwa kurangnya pengetahuan dan akses informasi menyebabkan seseorang memiliki keterbatasan pengetahuan tentang bahaya perilaku tidak sehat sehingga kurang motivasi untuk mengadopsi perilaku sehat (Fred C. Pampel, 2010). Penelitian lain menyatakan satu tahun pendidikan juga dapat meningkatkan pendapatan rata-rata sebesar $8 \%$ dan dapat mengurangi kematian dua kali 
lebih besar, baik secara langsung maupun tidak langsung (Pellet Kathleen, 2007).

Karakteristik responden pada penelitian ini hampir seluruhnya dengan pendidikan terakhir yaitu perguruan tinggi tetapi masih ada responden mengalami komplikasi yang seharusnya jika pendidikan tinggi akan dapat menyerap ilmu khususnya mengenai DM dengan baik sehingga tidak akan mengalami komplikasi. Hal ini sejalan dengan penelitian yang dilakukan oleh Meydani (2011) yang menunjukkan analisa bivariat bahwa tidak terdapat hubungan yang bermakna antara pengetahuan dengan upaya pencegahan komplikasi ( $\mathrm{p}>0,05)$, terdapat hubungan yang bermakna antara sikap dengan upaya pencegahan komplikasi $(\mathrm{p}<0,05)$, tidak terdapat hubungan yang bermakna antara persepsi dengan upaya pencegahan komplikasi ( $p>0,05$ ), dan terdapat hubungan yang bermakna antara motivasi dengan upaya pencegahan komplikasi ( $\mathrm{p}<0,05)$. Selain edukasi, faktor yang mungkin mempengaruhi terjadinya komplikasi yaitu kurangnya motivasi dalam diri, dukungan keluarga yang mungkin mempengaruhi responden untuk tidak patuh terhadap terapi yang dijalankan serta kurangnya penyuluhan dari tenaga kesehatan mengenai bagaimana dampak jika seorang penderita DM tidak patuh terhadap terapi yang seharusnya dijalankan.

Meningkatkan edukasi merupakan salah satu upaya yang dilakukan agar menurunnya angka kejadian komplikasi pada DM, namun hal ini pun tetap dipengaruhi oleh faktor motivasi dan dukungan keluarga.

\section{Hubungan antara Diet DM dengan Kejadian Komplikasi di Poliklinik RSUD Dr. Hasan Sadikin Bandung}

Temuan dari uji statistis mengenai hubungan diet DM dengan kejadian komplikasi didapatkan $p$-value $=0,02$ yang berarti lebih kecil daripada alpha 0,05 maka dapat disimpulkan bahwa ada hubungan yang signifikan antara diet DM dengan kejadian komplikasi pada pasien DM tipe 2.

Diet diabetes mellitus merupakan cara yang dilakukan oleh penderita diabetes untuk merasa nyaman, mencegah komplikasi yang lebih berat, serta memperbaiki kebiasaan makan untuk mendapatkan kontrol metabolisme yang lebih baik dengan cara menurunkan kadar gula darah mendekati normal dengan menyeimbangkan asupan makanan, insulin/obat penurun glukosa oral dan aktivitas fisik, menurunkan glukosa dalam urine menjadi negatif dan mengurangi polidipsi (sering kencing), memberikan cukup energi untuk mempertahankan atau mencapai berat badan normal serta menegakkan pilar utama dalam terapi diabetes mellitus sehingga diabetisi dapat melakukan aktivitas secara normal (Kariadi, 2009).

Hasil penelitian ini sejalan dengan hasil penelitian yang dilakukan oleh Yoga, 2011 yang bertujuan untuk mengidentifikasi hubungan antara 4 pilar pengelolaan Diabetes Melitus dengan keberhasilan pengelolaan Diabetes Melitus Tipe 2 dengan hasil analisis didapatkan odds ratio $(O R)=4,297$ dan nilai $p$ value $=0,008(<0,05)$. Hal ini menunjukkan bahwa orang yang mempunyai pola makan baik berisiko 4 kali untuk berhasil dalam pengelolaan DM tipe 2 dibandingkan dengan yang tidak baik dan secara statistik bermakna.

Kepatuhan terhadap Diet DM sangat berpengaruh terhadap pengendalian gula darah agar tidak menimbulkan komplikasi. Diet DM sangat dipengaruhi pula oleh pengetahuan, motivasi individu dan dukungan keluarga. 
Hubungan Antara Penanganan Diabetes Melitus : Edukasi dan Diet terhadap Komplikasi Pasien DM Tipe II (Hilda Novyanda)

\section{PENUTUP}

\section{Kesimpulan}

Temuan dari hasil penelitian yang sudah dilakukan menyatakan bahwa adanya hubungan yang signifikan antara edukasi dan diet DM dengan kejadian komplikasi. Edukasi mengenai DM yang buruk akan berpeluang lebih besar terhadap kejadian komplikasi. Diet DM yang buruk akan berpeluang lebih besar terhadap kejadian komplikasi.

\section{Saran}

1. Responden

Edukasi mengenai DM serta Diet DM yang tepat akan menurunkan terjadinya komplikasi, untuk itu diharapkan setiap responden mempunyai kesadaran serta motivasi terhadap dirinya dan dukungan keluarga agar mau menjalankan pilar penanganan DM.

2. Poliklinik Endokrin RSUP Dr. Hasan Sadikin Bandung

Agar perawat memberikan edukasi serta informasi kepada pasien DM dengan cara membuat leaflet, poster mengenai DM khususnya penanganan DM untuk mencegah terjadinya komplikasi dan tentunya selalu mensosialisasikan sesuatu yang baru untuk menangani DM dengan terus meng-update keilmuan mengenai DM khususnya. Perawat juga harus selalu mengobservasi pasien apakah pilar penanganan DM itu selalu dijalankan pasien dan observasi gula darah pasien serta komplikasi yang berkelanjutan serta berkolaborasi dengan tenaga kesehatan lainnya untuk mencegah terjadinya komplikasi.

Perawat juga dapat membuat perkumpulan DM (Forum Group Discussion) untuk mengetahui mengenai masalah yang dihadapi, dalam forum ini mungkin pasien akan lebih terbuka dan mengemukakan apa yang mereka rasakan dan perawat akan mengetahui apa yang sebenarnya mereka inginkan.

3. Bagi Peneliti Selanjutnya

Bagi peneliti selanjutnya agar meneliti mana yang lebih erat hubungannya antara pilar-pilar penanganan DM (edukasi, diet, olah raga, kepatuhan obat) dengan kejadian komplikasi.

\section{DAFTAR PUSTAKA}

American D, Association (ADA). 2005. Diagnosis and Clasification of Diabetes Mellitus. Diabetes Care. (Suplement1).

Ariani, Yesi. 2011. Hubungan antara Motifasi dengan Efekasi Diri Pasien DM Tipe2 di RSUP H. Adam Malik Medan. Jakarta: Fakultas Ilmu Kedokteran, Universitas Indonesia.

Arikunto, Suharsimi. 2010. Prosedur Penelitian. Jakarta: PT Rineka Cipta.

Azwar. 2003. Reabilitas dan Validitas. Yogyakarta: Pustaka Belajar.

Dharma, Kelana Kusuma. 2012. Metolologi Penelitian Keperawatan. Jakarta: CV. Trans Info Medika.

DinKes Kota Sukabumi. 2010. http://weightloss-surgery-dallas.com, published 9 Februari 2013.

Gannong, Willian F. 1999. Fisiologi Kedokteran. Jakarta: EGC.

Hidayat, A. Aziz Alimul. 2007. Metode Penelitian Keperawatan dan Teknik Analisis Data. Jakarta: SalembaMedika.

Holt T. Kumar. 2010. ABC of Diabetes Mellitus. A Jhon Willey Sons, Ltd., Publication. Chick ester. West Sussex. UK.

Lestari, Dian, Citrakesumatari, Sri'ah Alharini. 2013. Upaya Penanganan dan Perilaku Pasien Penderita Diabetes Melitus Tipe 2 di Puskesmas 
Maradekaya Kota Makassar. Makassar: Universitas Hasanudin.

Kariadi, Sri Hartini. 2009. Diabetes? Siapa Takut? Panduan Lengkap untuk Diabetesi, Keluargannya dan Profesionaldis. Bandung: PT Mizan Pustaka.

Malau MA. 2010. Hubungan Penyakit Jantung Koroner dengan Tingkat Hipertensi di RSUP H. Adam Malik Medan. Medan.

Meydani, Putri Yolla Dwi. 2011. FaktorFaktor yang Berhubungan dengan Upaya Pencegahan Komplikasi DM oleh Pasien DM di Poliklinik Khusus Penyakit Dalam RSUP Dr M. Djamil Padang. Padang: FIK Universitas Andalas.

Misdarini, Ariani Yesi. 2012. Pengetahuan DM dengan Kadar Gula Darah pada Pasien DM Tipe2.

Norris, S.L., Lau, J., Smith, S.J.,Schmid, C.H., \& Engelgau, M.M. 2002. SelfManagement Education for Adults with Type 2 Diabetes A Meta-analysis of the Effect on Glycemic Control. Diabetes Care, 25:1159-1171.

Notoatmodjo, Soekidjo. 2010. Metode Penelitian. Jakarta: PT Rineka Cipta.

PERKENI. 2002. Konsensus Pengelolan DM Tipe 2 di Indonesia. Jakarta : PB. PERKENI.

2006. Konsensus Pengelolaan dan Pencegahan Diabetes mellitus Tipe 2 di Indonesia. Jakarta : PB. PERKENI.
Purwanto, Nasrul Hadi. 2011. Hubungan Pengetahuan tentang Diet Diabetes Mellitus dengan Kepatuhan Pelaksanaan Diet pada Penderita Diabetes Mellitus. Denpasar.

Smeltzer, Suzanne C., Bare Brenda G. 2002. Buku Ajar Keperawatan Medikal Bedah Brunner \& Suddarth Ed.8 vol 2. Jakarta: EGC.

Sudjatmiko, Andika Nur. 2011. FaktorFaktor yang Berhubungan dengan Kemunculan Komplikasi Kronik Pada Penderita Diabetes Melitus Tipe 2 RSUD Kabupaten Kudus. Kudus.

Syaifuddin. 2010. Anatomi Fisiologi: Kurikulum Berbasis Kompetensi untuk Keperawatan dan Kebidanan, Ed.4. Jakarta: EGC.

Riyadi, Sujono. 2008. Asuhan Keperawatan pada Pasien dengan Gangguan Eksokrin dan Endokrin pada Pancreas. Yogyakarta: Graha Ilmu.

Vaughan DG, Asbury T. 2001. Oftalmologi Umum. Jakarta: WidyaMedika.

Waspadji, S. 2007. DM: Mekanisme Dasar dan Pengelolaannya yang Rasional dalam Penatalaksanaan DM Terpadu. Jakarta.

Yoga, Achmad Setyo. 2011. Hubungan antara 4 Pilar Penanganan Diabetes Mellitus dengan Keberhasilan Pengelolaan DM Tipe 2. FK UNPAD. 